\title{
Participatory Approaches to Unlocking Negative Perceptions on the Choice and Motivation to be a Primary School Teacher in Uganda
}

\author{
Alice Wabule ${ }^{1}$
}

(C) Uganda Martyrs University

\begin{abstract}
To achieve the goal of education for all, there is recognition of focusing on teacher's education to meet the increasing demand for qualified teachers. Many innovations have been implemented in Uganda to increase the number of trained teachers. However, despite this effort, there is concern about the declining numbers and the quality of candidates embarking on teacher education. This paper aims to show the social problem of low attraction to the teaching profession in Uganda. Based on empirical research, the paper explored a strategy for mitigation through a participatory action research approach which aimed at unlocking the negative perceptions and attitudes to the profession. It shows that teachers can secure a positive identity when taken through activities that make them feel recognised, valued and respected.
\end{abstract}

Key words $\cdot$ Career choice $\cdot$ Teacher training $\cdot$ Teacher identity $\cdot$ Motivation $\cdot$ Commitment $\cdot$ Action research

Les approches participatives pour libérer des perceptions négatives sur le choix et la motivation d'être un enseignant de l'école primaire en Ouganda

Résumé. Pour atteindre l'objectif de l'éducation pour tous, il y a reconnaissance de l'accent sur l'éducation de l'enseignant pour répondre à la demande croissante d'enseignants qualifiés. De nombreuses innovations ont été mises en cuvre en Ouganda pour augmenter le nombre d'enseignants formés. Toutefois, malgré cet effort, on s'inquiète de la diminution du nombre et de la qualité des candidats s'engageant dans la formation pour devenir enseignants. Cet article vise à montrer le problème social de la faible attraction de la profession d'enseignant en Ouganda, basé sur une recherche empirique, et explore une stratégie d'atténuation à travers une approche de recherche-action participative avec comme but de libérer les perceptions et attitudes négatives à l'égard de la profession d'enseignant. L'article montre que les enseignants peuvent obtenir une identité positive lorsqu'engagés dans des activités qui leur permettent de se sentir reconnus, valorisés et respectés.

Mots clés: le choix de carrière $\bullet$ la formation d'enseignant $\bullet$ L'identite d'enseignant $\bullet$ La motivation $\bullet$ l'engagement $\bullet$ la recherche-action

\section{Introduction}

Increasing the supply of qualified teachers has been highlighted as key to achieving Sustainable Development Goal 4 of providing quality education to ensure that all learners acquire knowledge and skills needed to promote sustainable development. Despite such a significant observation, it is also noted that new school teachers are needed most especially in Sub-Saharan Africa in order to fulfil the promise of universal primary and secondary education. In Uganda, the goal of government under the Universal Primary Education (UPE) programme is to ensure that every child

${ }^{1}$ Uganda Martyrs University, Email: awabule@umu.ac.ug 
should be in school and learning well (Busingye and Najjuma, 2015). Subsequently, the scheme of service for the teaching service personnel (Ministry of Education and Sports [MoE\&S], 2012), aims at developing professionally competent, wellmotivated and a reputable teaching force as a mechanism for improving the quality of teaching and learning in schools. In addition, government has taken keen interest to train teachers through both pre-service and in-service training (Agutiand Fraser, 2005 ) in order to increase the number of teachers that can respond to the increasing student enrolments. Nevertheless, like elsewhere in Africa, there is still a large gap with regard to the number of qualified and well trained teachers.

Whereas each country may have its own scale and reasons to account for the shortages, it is largely believed that the status of the teaching profession has declined during the last decades and the teaching job is no longer attractive. The World Bank (WB, 2007) reports on the state of education in Sub- Saharan Africa, indicating a low level of attraction to the teaching profession. A report from the Ministry of Education and Sports in Uganda (2003) revealed that the education system has failed to produce the necessary number of trained teachers, partly due to the inability of teacher training institutions to attract capable and interested students. This lack of interest to join the profession has led to the lowering of entry standards at teacher training institutions. A recent report on recruitment of students into teacher training colleges indicated that the majority of the admitted candidates attained third grade in national examinations (Daily Monitor, May 2016). This does not only compromise the quality of graduates from teacher training institutions but also hinders many from successfully completing their course. For instance, the high failure rates in teacher training colleges are blamed on the failure to attract capable students (Musoke, 2011; Gaynor, 1994 cited in World Bank, 2007; Munene, 2009; Kasente, 2010). It is believed further that low attraction to the teaching profession is having tremendous consequences on the professional quality of primary school teachers in Uganda (Musoke, 2011). For example, several studies point out that the choice to be a teacher is crucial for teacher motivation and job performance because it impacts on the self-esteem (Munene, 2009; Musoke, 2011). Accordingly, students who enrol in teacher training colleges feel inferior, sometimes fearing ridicule by their colleagues who manage to join higher secondary schools (Ssekamwa, 1997; Aguti and Fraser, 2005). Students who join the teaching profession with the feeling that it is the wrong profession for them, have little ambition, interest or ability to promote the image of teachers

Thus, developing knowledge about the people's motivations for joining the teaching profession becomes an important issue for both policy and research for government to achieve her strategy of enhancing quality education. Such knowledge could help policy makers, schools and teachers themselves to develop better ways of making the teaching profession more attractive. Thus, this article is structured in three sections. I begin by a review of the literature focusing on the argument that to be a teacher impacts on the teachers' motivations and attitudes to the profession. I then analyse evidence from the narratives of trainee teachers and tutors to show that there is a low attraction to the teaching job. The last section explores the extent to which 
participatory action research can be applied as strategy to enhance the teacher's attitudes to the profession.

\section{The choice to be a teacher}

The desire for well trained, skilled, and motivated teachers has become the greatest need not only in sub-Saharan Africa but in other countries (Lindqvist et al. 2014). Studies show that many countries are struggling to increase recruitment into the profession (Ax and Ponte, 2008; Sahlberg, 2011; Lindqvist et al. 2014) to cater for the increasing enrolment in schools. Several campaigns to attract young people to the teaching profession have been launched. Such strategies differ from one country to another. The majority focus on incentives and establishing alternative routes into the profession although they have succeeded less at achieving the desired results (Lindqvist et al. 2014; Ax and Ponte, 2008).

According to Lindqvist et al. (2014), the problem actually is that many students, including those that graduate from teacher training institutions have little interest in teaching. As a result, many of those that qualify as teachers tend to leave the profession after a few years as indicated by Kauckack and Eggen (2010). Sahlberg (2011) and Pollard et al. (2014) observe that teaching is perhaps, more than any other job, a profession that one can successfully practice only when bringing heart and personality into play. Individuals would wish to choose careers that match their personal values. Accordingly, merging personal values with job skills is significant in determining the level of attachment that people give to their work (Reybold, 2008). As Schön (1983) observes, the process of choice and formal socialisation in the profession play a great role in explaining the behaviour of individuals at the workplace, and the prestige and authority of professions. Thus, while education establishes formal qualifications for work, individual interest and situational factors have a role in determing one's commitment to work and conduct towards clients and peers.Thus, the values that individuals hold about the importance of teaching are critical to the decision to become teachers in the first place and sustaining motivation and resilience throughout one's career.

On the contrary, many young professionals and students find themselves in the profession without real interest in the values they are expected to promote (Schön, 1983). Lack of interest in a profession is likely to have a negative impact on professional practices because individuals will not have the intrinsic motivation. In most cases, this is likely to compromise the spirit of craftsmanship, where the desire to do the job well for its own sake is more important than just working for money (Sennet, 2008, cited in Tukundane, 2015).

Lindqvistet et al. (2014) argue that the factors related to working conditions may be less important in influencing early departures than the individual's perception of the profession. In a similar way, Kauchack and Eggen (2011) have established that the personal motivation and perception of the profession influences the way teachers think about themselves, their teaching practices and how they behave towards their 
colleagues and the children they teach. It also influences the professional identity formation and the way in which teachers envision who they are and their sense of belonging (Choi et al. 2016). This view is also supported by Sahlberg (2011), when he contends that the choice to be a teacher impacts one's identity and belonging. A positive choice for the profession forms a strong foundation for creating moral professionalism because it impacts on the intrinsic motivation that determines the level of commitment to the job.

Individuals who hold strong positive perceptions about teaching are more likely to have the necessary professional qualities. Such teachers portray high morale, which is important in the success of day-to-day routine teaching and learning process. They possess the inner spirit that drives them to exhibit confidence, cheerfulness, discipline and willingness to perform assigned tasks (Sahlberg, 2011; Ogamba et al. 2015). It has been proved that teachers with no interest at all usually engage in unprofessional practices like showing less interest in their work, being less caring to their students, lower tolerance for classroom disruption and use corporal punishments (Ogamba et al. 2015). Others show signs of depression and are often struggling to leave the profession. Hargreaves and Goodman (2006) point out that the current generation of teachers seem to be struggling with professional formation, which they partly attribute to the wider change movements in society as a whole. Therefore, many young teachers do not see any joy in teaching, but rather as a trail of grief. Although teachers with support from their colleagues could gradually begin appreciating themselves, the struggle to establish identity and social status overwhelms them and stifles the motivation and resilience to identify with the profession (Pollard et al. 2014).Whereas the existing literature does the mapping and understanding of the problem, it does not explore options for change which must not necessarily be of a general nature but context specific. Thus, this article reports on a study to fill this gap, at least for the primary education situation in Uganda. The study explores how the situation of choice and motivation to be a teacher and resultant situation of being a teacher is experienced from the teachers' point of view, and how teachers themselves can collaborate to find options for action to remedy the situation.

\section{Methodology}

This article reports on part of a larger study on teacher professional integrity issues, conducted in Uganda between December 2011 and December 2015. The study focused on teachers' perspectives on unprofessional and unethical behaviour, notably absenteeism, alcoholism and abuse of learners (Kasente, 2010; UWEZO, 2013). The initial interest was to establish the views of teachers on such behaviours, the reasons and meanings they attached to their practices and why certain things happened the way they did. The negative perceptions about the choice and motivation for teaching featured prominently in the discussions. Therefore, the article draws on a Focus Group Discussion (FGD) with 9 trainee teachers of a Primary Teacher Training College (PTC) level. The experience shared illustrates the challenges with the choice to be a teacher. The narratives of the trainees are supplemented with data from indepth interviews with primary school teachers, tutors in a teacher training college, 
retired teachers and key education stakeholders. Literature sources intended to analyse the negative social implications for the lack of attraction to the teaching profession in Uganda were equally employed.

The study incorporated an action research approach in order to allow for a study design that is not only limited to description (Boog, 2007) but also explores how integrity can be strengthened by starting from the teacher's point of view. It aimed to include the diversity of experiences of teachers through engaging with teachers over a period of four years employing democratic and participatory means of engagement (Bodorkos and Pataki, 2009). The study involved teachers themselves in dialoguing and subsequently exploring possible ways in which they could bring about improvements in their professional practices in the form of school-based improvements.

Considering the cyclic nature of action research (Stringer, 1999), the study upon which this article is based was undertaken in three phases. The preliminary phase involved collecting information from a cross-section of institutions, and gaining broad insights into the thinking and reasoning of a range of stakeholders on the status of the teaching profession. Four primary schools that included; Nakasero and Kabojja Primary Schools and then Bunyinza and St Edward Primary Schools were selected from both urban and rural settings respectively. In addition, Nyondo Primary Teacher's College was included in the study to establish how teacher training institutions were preparing teachers for the field of work. Fifty-five people were purposively selected because they were considered to be information rich (Creswell, 2012). Among these were 17 student teachers, 7 tutors, 19 teachers, 4 parents and 8 key persons. These participated formally either through in-depth interviews or by being involved in a focus group discussion. Thus, the study did not aim at testing a hypothesis but at digging into the problem to the point of data saturation (Hennink, Hutter and Bailey, 2011; Creswell, 2012).

The second phase entailed a prolonged stay in the field of study, interacting and mingling with the participants in order to enable them gradually open up to the researcher and their colleagues in sharing personal perceptions, experiences, motivations and interpretations (Hennink et al. 2011). The study then focused on one school in order to gain more commitment in working with teachers as partners in the research process. The process of participation and action in the third phase was directed towards creating positive change (Tukundane and Zeelen, 2015), employing a mixture of methods such as group discussions, feedback meetings, peer learning and workshops.

The data were mainly qualitative and narrative based, with the aim of eliciting inner views of the respondents. The narrative analysis (Tanyas (2012) cited in Tukundane and Zeelen (2015), was done by organising data according to the themes that were derived inductively in line with the emerging themes from the data. The intention was to make sense of what people say and what had been observed (Hennink et al., 2011). Codes were developed after a critical and multiple review of a cross-section of transcribed empirical text material (Flick, 2009). This was done with 
the help of the computer data analysis package, ATLAS.ti. Subsequently, the researcher examined, compared and contrasted meaningful patterns or themes which would not be obtained via statistical procedures (Hennink et al., 2011). Although attention was paid to the structural and social content of the story, more emphasis was put on what "was told" (Tukundane, 2015) and the meanings people attach to their experiences. Cognisant with the research ethics of confidentiality, the participants' identities were concealed by use of pseudonyms to minimise the linkages between the data and the persons who provided it.

\section{Findings}

This study aimed at tracing the various motivations of teachers in joining the teaching profession, rather than measuring exactly the prevalence of particular motivations. Nevertheless, it was observed that only a few teachers joined the profession willingly. The common expression, especially among the youthful teachers and the students at the PTC, was that they joined teaching as a last resort, and only wished to use teaching as a springboard to advance to other careers.

\section{Why I became a teacher: Negative feelings}

The focus group discussions and the interviews showed that the largest group of teachers and students in PTCs come from low socioeconomic backgrounds and could not afford the higher cost of education in other institutions of learning. Others indicated that their education was financed by either relatives or well-wishers. Their views pointed to the fact that many of them would have opted for different career choices if they had the opportunity of meeting the direct and indirect costs of main stream academic education. When asked during FGDs why they joined teaching, each student as represented by the participant number below, had their own testimony.

P2: For me, I joined because my home background was not all right ... there was no money at home. The parents advised me that I should go for a primary teaching course. [They said that] may be if you get money you will advance yourself in future. Thereafter, I decided to join this college.

P5: To me, I just bear with the situation because I am already in and I have to continue.

P8: To me, I do not feel well because as a person you might be planning to do something whereas when God has planned for you another one. You just say, maybe it was God's plan.

P4: I feel hurt but because of the situation I was brought this way... so I just endured with the situation. In future, when I qualify and I get money, I can leave this one [teaching], and join another profession.

P6: To me, in first term, it was like... but now I have joined the course that I never wanted. I normally refused to read books, and second term I still did not like reading, but now it is third term, and I have said it was God's plan. 
P3: On my side, on the first day I was told that after your Senior Four, you are going for a teaching course; I felt badly and cried the whole day. My mother had to advise me... I told her I am not going! She told me if you want, go for your nursing course, but then, there is no money. I said no. I had to inquire from my elder sister. She told me, as you see us now, there is no money. We know what you want to do, but just accept what mummy is telling you and go. Then in future when you succeed in life, you get something good. You can as well leave this one [teaching] and go to another one. So I had to accept her advice. By the time I joined here... those who saw me knew that it wasn't my wish. I used to cry every day. Then the people started counselling me... you endure... things happen. I had to forget everything, up to now. I accepted God's will. I now train to be a teacher ( FGD, teacher trainees, 28 September 2012).

The accounts of the student participants reflected that today's teachers enter the profession with different career interests. Feelings of resentment against teaching were also evident in the interviews with the newly qualified teachers. Remy's narrative below illustrates the circumstances that pushed him into teaching:

I never wanted to go teaching. Like I said, my family was of teachers; my mother, my father, and my elder brothers [were teachers]... The life they lived... it was not worthy. I grew up knowing teaching is bad. It is a teacher who lacks everything. It was a last resort. I had passed very well my O level; I had my good grades, but could not proceed because my parents could not afford the cost of higher education. My mother came and sat me down. She used very good words. I later realised half a loaf is better than none... But because of my good grades, I enjoyed it; I came out with very high grades. But I never liked teaching throughout the training because while there, I was still thinking I was in a wrong place. I took it as an academic course, totally academic (Remy, newly qualified teacher, 12 September 2012)

Another respondent with substantial years of teaching experience explained that he joined teaching because he did not acquire sufficient credits to secure him a course of his interest:

I sat my A level, but did not perform well, and I was admitted to a business college. However, Daddy said that I should go for a teaching course. I refused to go to a teacher training college. I run away from home and went to Masaka. You know, I wanted a place where I could settle down and re-sit my exams [to get better grades for higher education]. They invited an aunt who counselled me for some time... They counselled me and I ended up in a teacher training college (Robert, 14 September 2012)

The narratives by Remy and Robert just like that of the teacher trainees show that joining the teaching profession against one's wish accounted for the negative attitudes to teacher training during the time when they were mourning the decision to be teachers. For instance, even though they were convinced to enrol for a teaching course, they confessed that they held negative attitudes throughout the training. Remy's expression "I later realised half a loaf is better than none" could be one way of saying, 'I simply conceded because there was no alternative'. 
The graduates from PTCs confessed that they lack adequate skills and competencies to enable them to comprehend different pedagogical strategies, which most likely leads to poor achievement of learners:

\begin{abstract}
When I joined teaching, I think, honestly I was half-baked. Let me tell you because it was not easy for me. Because when I was training, I felt the course was too hard. The people who say so and so was born a teacher, then so and so was just trained but I think me, I was just trained. So, when I started teaching and I found those experienced teachers there, they challenged me. Whenever I would go to class to teach, they could find only mistakes in me... (Pearl, teacher, 18 September 2012)
\end{abstract}

One retired clergyman expressed feelings of displeasure associated with the recruitment of less interested individuals into the teaching profession. He stressed the importance of tightening the entry requirements and suggested that scrutinising the candidates was important in order to recruit only those with interest and ability:

\begin{abstract}
I think of the teacher of today... I pity him or her. I want to begin with the entry point of a teacher. Which teacher do we take to be trained as a teacher to teach children tomorrow? These teachers, some of them we just pick... Entry point is a big, big point... If you take a person that you just pick from the street or with poor grades or you just persuade them, when they come back, they do what they want. Sometimes, some of them just go to the colleges and come back when they don't have any morale to teach... So, I think we need to scrutinise which people we take for teaching courses so that tomorrow they come and teach very well. We should not take people... the least, who we think cannot go anywhere else. They are the ones who go and teach, and they go to teach the leaders of tomorrow (Samuel, retired clergy, 27 September 2012)
\end{abstract}

Another assumption commonly held by the students was that teacher training would lead them into acquiring better jobs in the future. While many participants with years of experience admitted to having advanced their careers through teaching (Wabule, 2016), such perceptions tend to be misleading because attaining a teaching certificate is not a guarantee for career advancement. Yet if teaching is only viewed from the perspective of obtaining better jobs, it increases the risk of having unsatisfied teachers who remain in the profession against their wishes. The frustration and demotivation that come with a failure to meet the goal of getting a 'better job' were perceived as contributing to the low sense of commitment to the standards of professional integrity. James and Jane voiced their concerns from the perspective of tutors:

It has become a job which is almost a last resort. Even during the intake, you find that people who pass always go for other studies or even other courses. But it is normally these ones who pass so weakly... that normally come to the colleges. So, it begins building up right from there... We try to make them change... try to put them right, prune them, but they do not behave to our expectations of a professional teacher. 
From that attitude, you expect least in terms of behaviour. This is a person who is not going to respect being a teacher because personal interest has never been there (James, tutor, 28 September 2012)

They come yet they wanted to go for another course but because of lack of funds, or the people who are caring for this person are not their biological parents because their parents passed away; so, they have been forced to become teachers. So, they are here but thinking, 'I wish I had another place'. They are not people who had interest but they just come because of circumstances, because they have nothing to do. So, [with] that attitude you expect least, because this person did not plan to become a teacher (Jane, tutor, 28 September 2012)

Tutors state that they find difficulties in training less interested students to acceptable professional standards. A participant explained that people give less preference to teaching as a career because it is perceived not to facilitate a viable standard of living. He pointed out that most students interpreted the teaching profession in relation to the economic gains that they will receive after qualifying. Moreover, it was noted that many students and teachers, due to social exposure, could easily compare their benefits, positively or negatively, with those of other people who serve in other professions.

\section{How I became a teacher: Positive feelings}

Whereas the narratives of teacher trainees were dominated by negative feelings about teaching, one participant at a FGD was more positive and confessed his unreserved passion for becoming a teacher:

To me, ah... I love the teaching profession, and I loved to be a teacher, uuh. If I was to miss primary [primary school teacher], then I would not miss to be a secondary teacher. Although I was advised by people, I already had that feeling of being a teacher. So, the advice they gave me was just to motivate or encourage me, but the desire to be a teacher already existed in me... uuh (Dick, teacher trainee, 28 September 2012)

Dick revealed later during the discussion that the desire and passion for teaching originated from his personal experiences, interactions and closeness to his teachers. In his view, teachers loved, cared, and interacted mutually with the learners, and were respected in the community. He looked forward to receiving the same respect after the course. Throughout the Focus Group Discussion, Dick struggled to convince his colleagues about the importance of teachers. While asserting his position against those who preferred to be nurses or lawyers, he argued that the social respect that was accorded to lawyers and nurses did not undermine the fact that teachers were the makers of society. Dick emphasised that teachers simplified life by guiding and imparting knowledge to those who serve in other professions. In a similar way, several participants confessed to have joined the teaching profession willingly. For instance, Joseph, an elderly teacher, indicated that his personal liking for the job and love for children inspired him. He also viewed the teaching profession as having 
offered him unlimited opportunities for lifelong learning, on job training, research and social exposure through participating in sports. Joseph affirmed that he felt physically and socially accepted in different work environments. He demonstrated that the strong love he had for teaching inspired him to abandon an administrative job which he perceived as not providing personal satisfaction. Recounting his preferred choice, he emphasised, "For you, when you love your job, you go there with one heart", which in our view, could mean having a steadfast commitment, a positive attitude and the desire to serve, despite the challenges one encounters. A lot transpired during the two-hour interview with Joseph, below I reproduce a summary of what he affirmed:

There are many reasons why I left working at the district. Discipline in clerkship was not good... In clerkship, the work was too much, always working, in the morning, in [sic] the night. You don't study a lot. So, what came out, I went to teaching... In teaching I got used to the books... In teaching you get education, you teach, you study. They give refresher courses like that. I also found playing football in teaching. It was not in clerkship. I used to have time to do other things... I had time to play and coach my friends... I had time to go for trips... to go for sports in other districts (Joseph, retired teacher, 26 April 2012)

Field experiences through observation and frequent interactions showed that teachers who were positive in embracing their professional duties, depicted higher self-esteem and enjoyed a better collegial relationship. Teachers revealed that their actions were embedded in the desire to be self-driven, being open to learning opportunities, accommodative and appreciative when confronting challenges. Kadima, a long serving teacher, disclosed:

I have a self-drive in me and I have feelings for the child... I also have mental preparation before I meet the child. I may not get monetary values per day, per week, but I have a sense of duty... It is me, because I don't think the school motivates me enough, but I feel I should... It is just a question of adjusting one's thinking... Why am I here? I am here to serve. Although I am not getting much as some other person, I am here to do my work (Kadima, 15 September 2012)

These narratives point to the importance of personal liking and having an internal drive as being useful in influencing the attitudes and practices of teachers, including the degree of commitment to the job and resilience during difficult times. Having interest in the job is also associated with hopeful attitudes, an optimistic view towards one's colleagues and enthusiasm for one's work (Ogamba et al., 2015). Nevertheless, such feelings of passion and satisfaction were expressed mostly by the retired and those teachers with several years of experience. Because of this, in our view, the perception of teaching as an honoured profession in the past could have had an influence on their aspirations and later on how they conducted their duties. It is the case that contemporary teachers are exposed to knowledge about new career openings that they perceive to be better. The current findings reflect those of previous studies (Musoke, 2011) but no strategy had been undertaken in Uganda to help teachers deal with the negative feelings of being in a profession against their wishes. 


\section{Working together to improve the attitudes of teachers}

Basing on the challenge of the choice and motivations to be a teacher, which impacted the teacher's morale and job commitment, our intervention set out to work jointly with a group of 21 volunteer teachers to design an intervention with the aim of helping them share ideas that are important for solving their problems. This was decided by the teachers themselves according to what they felt was important to them. My task was to provide guidance as an informed advisor (Wicks and Reason, 2009) so that we move a step away from addressing the general problems that teachers faced in the country to creating a special forum in which teachers expressed themselves.

\section{Dialogue conferencing as a forum for peer counselling}

Although several other innovations such as school-based informal learning activities for building different capacities of teachers were implemented (Wabule, 2016), this article is interested in looking at the item of peer counselling which was of paramount importance to the teachers. This need was expressed during different encounters with both trainees and teachers in the process of seeking ways of how to bring about certain improvements in the profession:

The first thing to do if we are to succeed is to help a teacher at cross-roads; those that are down trodden to change attitude. Let us put something in place that communicates the good things about teaching so that people out there can know that teaching is not bad. Now everyone knows that teaching is bad (Robert, 28 April 2013)

As teachers we don't appreciate the profession. We hide our profession because we don't want the public to know we are teachers. We are not proud of what we are. We do not appreciate what we are... this comes from the grassroots, because at college students are never told by the tutors that they should value the profession they have come to. Students just sit in class and are taught to become teachers. None of the tutors taught us that we should love the profession that we are going in. We may not have professional counsellors, but how do we put in place such measures in terms of peer counselling. We come up with a day when we can meet, share, and cry with each other. A problem shared is a problem half solved (Tina, 28 April 2013)

Teachers created an open and inclusive forum for discussions that enabled them share insights of their experiences in teaching. Undertaken within the action research framework of dialogue conferencing (Kyaruzi et al. 2015), different actors voluntarily brought up different perspectives and concerns for discussion. It involved a complex mixture of varying ideas that opened up opportunity for sharing dynamic knowledge (Wicks and Reason, 2009).This approach to peer counselling helped them to break away from feelings of self-pity, fear, isolation and discussed ways of coping with stress. They revealed that divisions that prevailed amongst staff were a barrier to effective collaboration and engagement, and kept them distant and silent about their 
problems. A session featuring the need to change the way teachers portrayed their image in public was held:

...we have perceived ourselves as inferior in society. Some will say, "For me, I am a mere teacher", and if you are saying that in the community, what are they going to do with you? We have not valued ourselves in the way we behave, in the way we talk, in the way we perceive ourselves. We have ideas that we have not put to use. We have portrayed the image that we are very poor... what has the public have to do with a poor person? A poor person will hardly be respected in society... conducting ourselves in a way that is unbecoming, let alone not producing good results (Daniel, head teacher, 23 November 2012)

By advocating a change in perceptions, the above participant also recounted his own experience and prior hesitation to join teaching, by disclosing that he had long changed attitude.

... Going to a TTC was not out of choice but it was circumstantial. I had an uncle of mine who actually persuaded me so much to go to teaching, and he was showing me the opportunity that whatever else I wanted to do, I would do it after getting that certificate. I didn't believe him that time, but today I am here to confess that. I think what he told me was... was really true, because I have been able to do other things... Frankly speaking, teaching was not in my brain. I went there because I was persuaded, but later, I came to like teaching... I have no regrets because I have liked it. I couldn't see at that time that there are many openings... I have been a teacher for the last 30 years and I am doing well... (Daniel, 23 November 2012)

Several teachers narrated experiences that depicted successful career lives in teaching. They asserted that through commitment and hard work, they had achieved material, social and educational benefits as much as their colleagues in other professions. They called upon fellow teachers to take charge of their destinies instead of lamenting. They considered the values of creativity, discipline and self-reliance as earning teachers respect in society. Kadima, who had worked as a primary school teacher in an urban school for the last 37 years, maintained that teaching can be rewarding with proper planning:

I have got a house in Kampala [city]. I live in my own house. I bought 10 acres of land out of my job, but I didn't cheat anybody. Other people fail to live within the limits of their economy because they stretch to live other people's lives. Teachers should adjust and live within their own means... they should not live the life of other people (Kadima, 15 September 2012)

Both Kadima and Daniel argued that teachers should utilise their resources effectively and creatively, stressing that no amount of money was enough. One teacher suggested that using free time to engage in constructive activities could supplement the teacher's income rather than presenting themselves as vulnerable. 
Several teachers disclosed that they benefited greatly by engaging in a range of activities such as farming and private businesses. This, of course, may have negative repercussions such as giving less priority to the teaching responsibility (Wabule, 2016); nevertheless, it enabled the teachers to improve on their welfare and social status.

Reflecting on, and sharing past experiences, helped teachers who had in the beginning showed signs of negative sentiments about the teaching profession to gradually appreciate the necessity of developing a positive attitude, as pointed out by Robert, a young serving teacher in an urban school.

Although I joined teaching because of circumstances, I do not regret. When I got here someone told me, it was Mr Stevo. He said to me, you have come here a teacher, you need to work hard, you need to make your life better, so that tickled my mind... (Robert, 16 September 2012)

Robert explained that teaching had provided him time and opportunities to contribute to sports and interfaced with high ranking people on several sports committees in the city. He pointed to this as having gained him exposure and boosted his esteem and self-confidence.

I have been able to serve in different areas after work simply because of this [teaching]. If I was serving in another area [job], I would be relating with maybe [people of low status]. But because I am in town here and I am assured of an address, therefore I can see that I move after work, attend meetings, play games. For example, I go for basketball in the evening. What I wanted was a place that would enable me to exploit my potential... I have a lot of confidence in myself... (Robert, 16 September 2012)

Such stories give an impressive view of people who entered the teaching profession under unique circumstances, but nevertheless, point to the fact that they came to appreciate and like what they do as a result of being nurtured positively in the schooling system. One participant at an evaluation meeting pointed out:

In the past, if you could recall, we were able to know through our discussions that may be we are also, sometimes in the wrong because it takes humility for one to realise their problem...Y You remember sharing our experiences about how each of us was able to join teaching. You know, we now realised that we are two different people but we have to work together (Willard, 30 November 2015)

Furthermore, Willard explained that participation in this research enabled teachers change their general outlook to life and started perceiving the profession in a more positive way:

... And this is one of the groups we have had in the country where a teacher talks about himself. Not lamenting but looking at how he can turn around his 
situation to a better situation, because normally when we gather, it is about our problems...the government is not giving us this, we are having this... At least we now have a feeling that there is someone who cares about the plight of teachers... (Willard, 30 November 2015)

\section{Conclusion}

This article builds on the consensus among experts that the choice to be a teacher significantly impacts the teacher's morale, commitment and identity. Reports on teacher performance in Uganda, just like elsewhere in sub-Saharan Africa, indicate a less caring attitude for children, higher rates of absenteeism, alcoholism and a failure to teach effectively and efficiently even when teachers are physically present in school (UWEZO, 2013; Tao, 2013,). This study set the task of tracing motivations for joining the teaching profession among PTC entrants and young teachers. The study draws upon narratives of teachers that elucidate the different circumstances that pushed them into teaching. Whereas the narratives indicate that some individuals join teaching willingly, the majority of teachers felt that they were in the wrong profession. Those with feelings of being in a wrong profession were ashamed of their identity, tended towards self-pity, and had low morale. The negative perceptions imply that such teachers were less likely to be nurtured into securing the necessary professional competencies, which seemed to account for the deterioration in professional integrity. Moreover, many teachers lack adequate pedagogical competencies which probably could be due to their low academic grades at the time of enrolment, but also because they do not put effort to grasp what is taught to them during training (Wabule, 2016).

Studies have pointed to the poor working conditions in schools, decreasing wages and lack of career prospects (Sumra, 2004; Tao, 2013; Akkari and Lauwerier, 2015) as the major contributing factors to the low attraction and motivation of teachers. As a result much effort has been directed at improving the working conditions and increasing incentives (Lindqvist et al. 2014; Sahlberg, 2011). However, little has been done to change the low public perceptions about choosing teaching for a career or change the attitudes of the teachers who are ushered into the profession without much liking for it. Sahlberg, (2011) and Tao (2013) show that job attraction is a complex issue involving more than wage related issues. They point to a supportive environment, social respect, involving teachers in the decision making processes and the ability of teachers to voice their concerns at the national level as being critical to teacher identity development.

Studies indicate that failure to involve teachers in confronting their issues in an open and transparent forum lead them to cling to feelings of marginalisation, isolation and neglect (Dworkin, 1987). This study set out to work jointly with teachers as partners to design activities that enabled them to reflect on their practices, and repair negative feelings and attitudes. The study made greater achievements in revitalising the attitudes of teachers who had lived with feelings of self-pity, lack of confidence and self-esteem, by opening up to speak about things that hurt them. The enthusiasm 
that was portrayed during the peer counselling sessions demonstrated that teachers can succeed at reaching a desirable level of professional integrity if they were taken through processes that promote collaboration, openness and dialogue. In any case, they were not compensated for spending enormous amounts of time to participate in the research. Instead, a feeling of being valued, respected, recognised and listened to as opposed to prior stigma, disgust and isolation, boosted their morale. This served as a break away from the common thinking that it was only extrinsic incentives that could motivate teachers develop positive attitudes to their work.

In conclusion, I argue that the Ugandan government should create conditions in which teachers feel recognised, appreciated and good about themselves and each other so as to develop feelings of self-worthiness and accomplishment of their work. Talking positive about the profession compared to the current negative publicity of teachers should serve as a way of attracting competent young men and women into the profession.

\section{References}

Aguti, J. N., \& Fraser, W. J., 2005.The challenges of Universal Primary Education (UPE) in Uganda through distance education programmes. African Education Review, 2(1) 91-108.

Ahimbisibwe, P., 2015. Teachers Incompetent. The Daily Monitor (Kampala) 23 April

Akkari, A., \& Lauwerier, T., 2015.Teachers and the quality of basic education in Sub-Saharan Africa. Education research and foresight. UNESCO working papers.

Braten, I., \& Ferguson, L. E., 2015. Beliefs about sources of knowledge predict motivation for learning in teacher education. Teacher and Teacher Education, 50: 13-23.

Boog, B., 2007. Quality of action research: Reciprocal understanding of academic researchers and participating researchers. In Ponte, P., \& Smit, H. J. (eds.), The quality of practitioner research: reflections on the position of the researcher and the researched. Rotterdam: Sense publishers.

Bodorkos, B., \& Pataki, G., 2009. Local communities empowered to plan? Applying PAR to establish democratic communicative spaces for sustainable rural development. Action Research, 7(3) 313-334.

Choi, E., Gaines, R. E., Park, H. J., Williams. K.M., Schallert, D. L., \& Lee, J., 2016. Small stories in online classroom discussions as resources for pre-service teacher's making sense of becoming a bilingual educator. Teaching and Teacher Education, 58: $1-16$.

Creswell, J. W., 2012. Education research: Planning, conducting and evaluating quantitative and qualitative research, (4th ed.). Boston: Pearson.

Dworkin, A.G., 1987. Teacher burnout in the public schools: Structural causes and consequences for children. Albany: State University of New York Press.

Evans, D. R., \& Odaet, C. P., 2000. Teacher education in Uganda, 1990- 2000.A preinvestment study. A Report for the Ministry of Education. Kampala, Government of Uganda. 
Flick, U., 2009.An introduction to qualitative research $\left(4^{\text {th }} \mathrm{ed}\right)$. London: Sage publications.

Foley, C., \& Murphy, M., 2015. Burnout in Irish teachers: Investigating the role of individual differences, work environment and coping factors. Teaching and Teacher Education 50: 46-55.

Griffin, R. (ed). 2012. Teacher education in Sub-Sahara Africa: closer perspectives: Annual report of Centre for Global Development. United Kingdom: Oxford Symposium Books Limited.

Halsey, F. R., \& Vegas, E., 2009. No more cutting classes? Reducing teacher absence and providing incentives for performance. World Bank: The World Bank Development Research group.

Hangreaves, A., \& Goodson, I., 2006. Educational change overtime? The sustainability and non-sustainability of three decades of secondary school change and continuity. Education Administration Quartely. 42 (1) 3-4

Hennink, M., Hutter, I., \& Bailey, A., 2011.Qualitative research methods. London: Sage Publications.

Higgins, L., \& R. Rwanyange., 2005.Ownership in education reform process in Uganda. Journal of Comparative Education, 3(1) 7-26.

Hyland, N. E., 2009. Opening communicative space with teachers investigating race and race in their own practice. Action Research 7(3) 335-354.

Kaahwa, M. G., 2005. Teacher education in the changing society: Strategies to meet the new demands for teachers. Kampala: Sure Technical Association.

Kasente, D., 2010. Enhancing the quality of primary education in Uganda. A case for improved literacy and improving the quality of teaching. Kampala: Fountain Publishers.

Kauchak, D., \& Eggen, P., 2011. Introduction to teaching; Becoming a professional, (4th ed.). Boston: Pearson. New Jersey: Pearson Education.

Kyaruzi, A., Gjotterud, S., \& Krogh, E., 2015. Dialogue conferences and empowerment: Transforming primary education in Tanzania through cooperation. Educational Action Research 24 (2) 300-316.

Lindqvist, P., Nordanger, K.M., \& Carlsson, R., 2014.Teacher attrition the first five years- A multifaceted image. Teaching and Teacher Education 40: 94-103.

McNiff, J., \& Whitehead, J., 2009. Doing and writing action research. London: Sage Publications.

Ministry of Education \& Sports, 2003.Teacher issues in Uganda. Kampala, Uganda.

Ministry of Education \& Sports, 2005. State of Uganda's population report: Quality education; a foundation for achieving Uganda' middle income status. Kampala, Uganda.

Ogamba, J. K., Kadenyi, M. M., \& Ngaruiya, B.N., 2015. Effect of teacher's morale on standard eight pupils' academic achievement in public primary schools in Marani sub-county, Kenya. International Journal of Scientific and Research Publications 10: 1-9. [Online] Available From: www.ijsrp.org [Accessed May 17 2016].

Munene, J. C., 2009. The management of Universal Primary Education in Uganda. Addis Ababa, organisation for Social Science Research in Eastern and Southern Africa (OSSREA). 
Musoke, G., 2011. The impact of poor working conditions on teacher's training in Uganda. A case study of primary school teachers in Kamuli district, 1945- 2005. Makerere University, Un-published Master's thesis.

Pollard, A., Black-Hawkins, K., \& Hodges, G. C., 2014. Reflective teaching in schools. London: Bloomsbury Publishing Plc.

Sahlberg, P., 2011. Finnish Lessons: What can the world learn from the educational change in Finland? New York and London: Teachers College Press.

Schön, D.A., 1983. The reflective practitioner: How professionals think in action. New York: Basic Books.

Song, L., \& Kenton, J. M., 2010.Action research in schools: The practitioner's perspective. Action Research, 10 (3) 1-10.

Ssekamwa, J., 1997. A history of education in Eastern Africa. Kampala: Kampala Bookshop.

Stringer, E. T., 1999.Action Research ( $2^{\text {nd }}$ ed.). Los Angeles, CA: Sage Publications.

Sumra, S., 2004.The living and working conditions of teachers in Tanzania. A research report. Dar es Salaam: Haki-Elimu.

Tao, S., 2013. Why are teachers absent? Utilising the capability approach and critical realism to explain teacher performance in Tanzania. International Journal of Education Development 33(1) 2-14.

Tiberondwa A. K., 1975. The teaching profession in Uganda, 1877-1972: A study of policy changes. Makerere University, Kampala. Unpublished $\mathrm{PhD}$ dissertation.

Tukundane, C, \& Zeelen, J., 2015. Using participatory action research to improve vocational skills training for marginalised youths in Uganda: Experiences from early school-leavers' project. International Journal of Training Research, 13(3) 246-261.

UNESCO, 2009. Evaluation of the Teacher Training Initiative for Sub- Saharan Africa (TTISSA): Education sector, Capacity Trust and Pedium. $\mathrm{ED} / \mathrm{HED} / \mathrm{TED} / 2009 / \mathrm{PI} / 58$.

UWEZO Uganda., 2013. Are our children learning? Annual learning Assessment report.

Kampala Uganda. [Online] Available From: www.uwezo.net [Accessed 7 September 2015).

Wabule, A., 2016. Continuous Professional Development: What role and Who Benefits? Reflections on teacher profession development in Uganda. African Education Review Journal 13(3-4) 141-156

Wicks, P.G. \& Reason, P., 2009. Initiating action research: Challenges and paradoxes of opening communicative space. Action Research 7(3) 243-262

World Bank, 2007.Recruiting and retraining secondary school teachers and principals in Sub-Saharan Africa. Working paper 99, Africa Human Development Series.

\section{Author Biography}

Alice Wabule (PhD) works as a Lecturer in the School of Arts and Social Sciences at Uganda Martyrs University. Her research interests include applied ethics, community empowerment, and good governance. 